\title{
IfIISGUC.ORG
}

"İȘ, GÜC̣" ENDÜSTRi ilLișKiLERI VE INSAN KAYNAKLARI DERGISi

"IS, GUC" INDUSTRIAL RELATIONS AND HUMAN RESOURCES JOURNAL

\section{Örgüt Depresyonu Ölçeği'nin Geliştirilmesi ve Psikometrik Niteliklerinin Belirlenmesi}

Development Of An Organization Depression Scale And Determination Of It's Psychometrical Qualifications

Öğr. Gör. Dr./ Ank.Üniv. Eğit. Bil.Fak./ A.Ü.E.B.F. PDR Anabilim Dalı

Ocak/January 2011, Cilt/Vol: 13, Say1/Num: 1, Page: 39-50 ISSN: 1303-2860, DOI: 10.4026/1303-2860.2010.0164.x

Makalenin on-line kopyasına erişmek için:

http://www.isguc.org/?p=article\&id=447\&vol=13\&num=1\&year=2011

To reach the on-line copy of article:

http://www.isguc.org/?p=article\&id=447\&vol=13\&num=1\&year=2011

Makale İçin İletişim/Correspondence to:

Sevgi SEZER, sszr2002@yahoo.com 
(C) 2000- 2011

"İşGüç" Endüstri İlişkileri ve İnsan Kaynakları Dergisi

"İşGüç" Industrial Relations and Human Resources Journal

Ocak/January 2011, Cilt/Vol: 13, Say1/Num: 1

ISSN: 1303-2860, DOI: 10.4026/1303-2860.2010.164.x

Editör/Editor-in-Chief

Aşkın Keser (Kocaeli University)

Editör Yardımcıları/Co-Editors

K.Ahmet Sevimli (Uludağ University)

Gözde Yılmaz (Kocaeli University)

Uygulama/Design

Yusuf Budak (Kocaeli Universtiy)

\author{
Yayın Kurulu / Publishing Committee \\ Dr.Zerrin Firat (Uludăg University) \\ Doç.Dr.Aşkın Keser (Kocaeli University) \\ Prof.Dr.Ahmet Selamoğlu (Kocaeli University) \\ Yrd.Doç.Dr.Ahmet Sevimli (Uludağ University) \\ Yrd.Doç.Dr.Abdulkadir Şenkal (Kocaeli University) \\ Yrd.Doç.Dr.Gözde Yilmaz (Kocaeli University) \\ Dr.Memet Zencirkıran (Uludağ University)
}

Uluslararası Danışma Kurulu / International Advisory Board

Prof.Dr.Ronald Burke (York University-Kanada)

Assoc.Prof.Dr.Glenn Dawes (James Cook University-Avustralya)

Prof.Dr.Jan Dul (Erasmus University-Hollanda)

Prof.Dr.Alev Efendioğlu (University of San Francisco-ABD)

Prof.Dr.Adrian Furnham (University College London-İngiltere)

Prof.Dr.Alan Geare (University of Otago- Yeni Zellanda)

Prof.Dr. Ricky Griffin (TAMU-Texas AEM University-ABD)

Assoc. Prof. Dr. Diana Lipinskiene (Kaunos University-Litvanya)

Prof.Dr.George Manning (Northern Kentucky University-ABD)

Prof. Dr. William (L.) Murray (University of San Francisco-ABD)

Prof.Dr.Mustafa Özbilgin (University of East Anglia-UK)

Assoc. Prof. Owen Stanley (James Cook University-Avustralya)

Prof.Dr.Işık Urla Zeytinoğlu (McMaster University-Kanada)

Danışma Kurulu / National Advisory Board

Prof.Dr.Yusuf Alper (Uludağ University)

Prof.Dr.Veysel Bozkurt (Uludağ University)

Prof.Dr.Toker Dereli (Işık University)

Prof.Dr.Nihat Erdoğmuş (Kocaeli University)

Prof.Dr.Ahmet Makal (Ankara University)

Prof.Dr.Ahmet Selamoğlu (Kocaeli University)

Prof.Dr.Nadir Suğur (Anadolu University)

Prof.Dr.Nursel Telman (Maltepe University)

Prof.Dr.Cavide Uyargil (İstanbul University)

Prof.Dr.Engin Yildırım (Sakarya University)

Doç.Dr.Arzu Wasti (Sabancı University)

Dergide yayınlanan yazllardaki görüşler ve bu konudaki sorumluluk yazarlarına aittir.

Yayınlanan eserlerde yer alan tüm içerik kaynak gösterilmeden kullanılamaz.

All the opinions written in articles are under responsibilities of the outhors.

None of the contents published can't be used without being cited. 


\title{
Örgüt Depresyonu Ölçeği'nin Geliştirilmesi ve Psikometrik Niteliklerinin Belirlenmesi *
}

\author{
Development Of An Organization Depression Scale And \\ Determination Of It's Psychometrical Qualifications
}

\author{
Sevgi SEZER \\ Öğr. Gör. Dr./Ank.Üniv. Eğit. Bil.Fak./ A.Ü.E.B.F. PDR Anabilim Dalı
}

\begin{abstract}
Özet:
Bu araştırmanın amacı, örgüte yayılmış bir hareketsizlik, saplanıp kalmış olma hali, sıklıkla geleceği planlamada yetersiz kalma, örgütteki bireylerin gelecekte ne yapacakları hakkında bir vizyonlarının olmayışı ve denemekten vazgeçmiş halde olmaları (Bilchik, 2000:35) olarak tanımlanan örgüt depresyonunu ölçmek amacıyla "Örgüt Depresyonu Ölçeği"ni geliştirmektir. Örgüt Depresyonu Ölçeği'ni geliştirmek için ilk olarak 55 maddelik madde havuzu oluşturulmuştur. Yedi uzmanın görüşleri sonunda 55 madde 45 maddeye indirilmiştir. 45 maddelik taslak form lise ve ilköğretim ikinci kademe okullarında çalışan 282 öğretmene uygulanmıştır. Ölçeğin yapı geçerliği için uygulanan açımlayıcı faktör analizi sonucunda "Örgüt Depresyonu Ölçeği"nin .30'un altında faktör yük değeri veren 3 maddesi ölçekten çıkartılmış, geriye kalan 42 madde tek faktör altında toplanmıştır. Bu faktörün tek başına açıkladığı varyans \%38.384 ve Cronbach-Alpha güvenirlik katsayısı ise 0.94'tür. Geçerlik için, Örgüt Depresyonu Ölçeği, Maslach Tükenmişlik Envanteri ile birlikte 35 kişilik bir öğretmen grubuna tekrar uygulanmış ve benzer ölçekler geçerliği incelenmiştir. İki ölçeğin toplam puanları arasındaki korelasyon katsayısı $r=.77$ şeklinde, gerçekleşmiştir. Örgüt Depresyonu Ölçeği 35 kişilik öğretmen grubuna 3 hafta arayla tekrar uygulanmış ve test tekrar test güvenirlik puanları; $r=.91$ bulunmuştur.
\end{abstract}

Anahtar Sözcükler: Örgüt, depresyon, örgüt depresyonu, ölçek geliştirme, geçerlik, güvenilirlik.

\begin{abstract}
:
The aim of the research is to develop an "Organizational Depression Scale" to measure the organizational depression which can be described as a state of inertia and being stuck across the organization, individuals in the organization frequently failing to plan the future, absence of a vision among them about what to do in the future and making no effort (Bilchik, 2000:35). First of all, including 55 an items-pool, was created to develop the "Organizatioaln Depression Scale". These 55 items were reduced to 45 after the review of seven experts. 45 items draft form was applied 282 teachers who are working in different primary and secondary schools. According to the results of exploratory factor analysis, the items were collected under one factor except the items with factor loadings that are under .30. This factor explains for \%38.3 of variance and it's Cronbach-Alpha coefficient is 0.94. The Organizational Depression Scale and the Maslasch Burnout Inventory were administered to 35 of teachers to test the validity of the scale. The correlational coefficient between the total scores of these two scales wase found as .77 . The Organizational Depression Scale was administered to a group of teachers ( $n=35)$ after a 3 weeks interval and the test-retest reliability coeffficent was found as $r=.91$.
\end{abstract}

Key words: Organization, depression, organizational depression, scale development, validity, reliability.

* Bu çalışma "Bilişsel davranışçı yaklaşımla bütünleştirilen hobiterapi programının bir eğitim kurumunun örgüt depresyonu üzerindeki etkisi" isimli doktora tez çalışmasından üretilmiştir.Bahçeşehir Üniv.Uluslarası PDR Kongresi (2008)'nde bildiri olarak sunulmuş̧ur. 


\section{GiRiş}

Hastane, cezaevi, fabrika, okul gibi gerek özel gerekse de devlet sektöründe yer alan birçok kurum toplumun en temel örgütsel yapılarını oluşturmaktadır. Örgüt; belli amaçlara ulaşmak için bir araya gelmiş insanların, karşılıklı işbirliği ve koordinasyon içinde, ortak hedeflere yönelik çabalarından oluşan grup olarak tanımlanmaktadir (Aytaç, 2004:189). Bu çalışmada örgütsel bir yapı olarak okul seçilmiştir. Bilindiği üzere okullar, bir toplumun geleceği olan bireyleri, topluma etkin olarak katılacak yaşa gelene kadar yaşama hazırlayıcı bir eğitim verirler. Böylece okullar yoluyla bireylerin gelişimi ve toplumsallaşması sürecine yön verilmektedir. Bu nedenle okulun örgütsel yapısı içindeki olumsuz bir gelişme bütün bir toplumu ilgilendirir.

20'inci $\mathrm{yy}^{\prime} ı$ sonlarında örgütlerdeki uyum konusuna olan vurgunun yerini patolojik yaklaşımlar almıştır. Uzmanlar örgütlerin de bazen hedeflerinden uzaklaştığ 1 ve örgütlerin hedeflerine ulaşamadıklarında insanlar gibi psikolojik tepki gösterdiklerine dikkat çekmişlerdir. Örgüt depresyonu, paranoid örgüt, obsesif kompulsif örgüt, örgütsel anksiyete, örgütsel travma örgütlerin gösterdikleri psikolojik tepkilerden bazılarıdir (Brunsson,1986:166; Frankel,1992:445; Scurlock, 1995:10 ; Cohen ve Cohen, 1993:120; Barton, 1994:20; Bilchik, 2000:35; Frankel, 2002: 1; Overby, 2002:1; Mariott, 2005:3 ; Schwarz, 2007:23; Baruch ve Lambert, 2007:86)

Cohen ve Cohen'e (1993:2) göre örgüt, bir örgütü oluşturan bireylerin kişiliklerinden farklı olarak kendi kişiliği ile kendine özgü bir varlıktır. Özel bir amacı gerçekleştirmek için oluşturulmuştur ve bir lideri vardır. Genel amacı desteklemek için çeşitli rol ve görevleri olan üyeleri vardır. Topluluğu oluşturan bireyler akılcı ve sevecen olabilirler. Ama onlarm her biri bireysel olarak hareket ettiği zaman, topluluk olarak genel hedeflerinden uzaklaşmaya başlayabilirler. Bu duruma hem olayların özel bir etkileşimi hem de bireylerin kişilikleri yol açar. Böylece topluluk kendini ve kendisine ait bir yaşamı yaratır. Aynı yazarlara göre bireyler bir örgüt dinamiğinin parçası oldukları zaman akılcı olmayan davranışlarının nedenlerini açıklayamazlar. Eğer bir örgüt kendi kişiliğini geliştirirse, o zaman bu örgüt insanlar gibi psikolojik olarak hasta da olabilir. Bu nedenle örgütlerdeki bu hastalıklar da bireylerin hastalıklarıyla ayn isimlerle tanımlanabilir. Bu hastalıklar aynen bireyler için söz konusu olduğunda kullanılan metodlarla tedavi edilebilir (Cohen ve Cohen, 1993:3). Cohen ve Cohen (1993:7) örgütlerde gözlenmesi muhtemel bütün patolojik durumları klinik psikolojik hastalıkların sınıflamasina uygun olarak psikozlar ve nevrozlar şeklinde ikiye ayırmışlarıdır. Psikozlar; manik davranış, manik depresyon, şizofreni ve paronoya'dan oluşurken, nevrozlar; nevrotik davranış, depresyon, obsesif kompulsiyon, post travmatik sendromdan oluşmaktadır. Araştırmacılar ayrıca "Organizational Health Analyzer (Örgütsel Sağlık Analizi)" (Cohen ve Cohen, 1993:175) isimli bir ölçme aracı ile bu hastalıkların nasıl tanılanabileceğini göstermişlerdir.

Bu çalışmada örgütlerde gözlenen bu patolojik durumlardan "örgüt depresyonu" ele alınmıştır. Örgüt depresyonunu anlayabilmek için "öğrenilmiş çaresizlik" davranışını, bunun sonucu ortaya çıkan örgüt nevrozunu ve klinik psikolojik bir hastalık olarak depresyonu tanımlamak faydalı olacaktır.

Hastalıkl1 örgütleri inceleyen Frost (1985; Akt; Güler, 2006:72), bir örgüt için nevrotik tanısının konulmasında en önemli nedenin "öğrenilmiş çaresizlik" olduğunu belirtmiştir. Bireyin kontrol yoksunluğu sonucunda kendi yetkinliğine olan inancın zayıflaması ile sorunlarla baş etmede pasifleşmeyi ifade eden öğrenilmiş çaresizlik, 1960 ve 70'lerde ilk defa Seligman ve arkadaşları tarafından köpekler üzerinde yapılan deneylerde gözlenmiş ve o zamandan bu yana psikolojide önemli bir yere sahip olmuştur. Frost öğrenilmiş çaresizliğin bir örgütü nasıl nevrotik yaptığını şu şekilde tanımlamaktadır;

“Örgütün sonuçları etkileyebilmek için hiçbir şey yapamadığını görmesi çaresiz olma- 
sına yol açmaktadır. Sonuçları etkilemek adına, sürekli olarak başarısızlık yaşayan örgüt "öğrenilmiş çaresizlik" sergileyecektir. Ardı sıra gelen başarısızlıklar o kadar etkilidir ki, örgütün (veya bağh olan çalışanın) koşulları değ iştirebileceği bir durum söz konusu olduğunda bile, örgüt (çalışan) acizlik içinde hareketsiz kalır. Öğrenilmiş çaresizlik örgütü nevrotik yapar. Örgüt içsel kontrolünü kaybederek, başarmın kendinden dışarıda tamamen şansa ve çeoresel etkenlere ve koşullara bağhl olduğuna inanır." (Frost, 1985; Akt; Güler, 2006:26)

Bu süreç içerisinde birçok araştırmacı öğrenilmiş çaresizlik ve depresyon arasındaki benzerliğe hatta öğrenilmiş çaresizliğin bir sonucu olarak depresyonun gelişmesine dikkat çekmiştir (Güler, 2006:26). Nevrotik bir alt yapı depresyona götüren süreci hızland1racaktır. Örgüt içinde çalışanın kontrol olanağına sahip olamaması, yeni teknolojilerin olumsuz etkilerinin ve örgüt içinde öğrenme olanaklarının kısıtlı olması öğrenilmiş çaresizliği körükleyebilecek faktörler olarak gösterilmektedir (Güler, 2006: 79).

Klinik bir hastalık olarak depresyon bireyin yaşamının hemen her alanında; iş, aile, sosyal yaşam olmak üzere bozulmalara yol açan psikolojik bir hastalıktır. Depresyondaki birey işine devam edememekte, sosyal çevresi ile iletişimini kesmekte giderek daha fazla içe kapanmaktadır. Beck ve Alford (2009) depresyonu aşağıdaki belirtilerle tanımlamıştır;

1-Kişinin ruh halinde belirgin bir değişiklik; hüzün, yalnızlık, ilgisizlik.

2-Kendini suçlayan (self reproache) olumsuz bir benlik kavram.

3-Gerileme (regression) ve kendini cezalandırma istekleri; kaçma, saklanma veya ölme isteği.

4-İstem dişı değişiklikler; anorexia (yemek yemek istememenin sonucu olarak gelişen yeme bozukluğu), uykusuzluk, libido kayb1.

5-Aktivite düzeyinde değişim; geciktirme veya ajitasyon.

Tedavi uygulanmadiğ 1 takdirde depres- yondaki birey kendine ve çevresindeki bireylere zarar vermeye devam edecektir. Benzer bir durum örgütler için söz konusu olduğunda bütün bir örgütün ilgi kaybı, gerileme isteksizlik gibi belirtiler göstermesi, örgütün hedeflerinden uzaklaşması ve kendisini bu durumdan çıkarmak için herhangi bir çaba içine girmemesi söz konusu olmaktadır. Bu durum yani örgüt depresyonu Bilchik (2000: 35) tarafından şu şekilde tanımlanmıştır; "örgüt depresyonu, örgüte yayılmış bir hareketsizlik, saplanıp kalmış olma hali, sıklıkla geleceği planlamada yetersiz kalma, örgütteki bireylerin gelecekte ne yapacakları hakkında bir vizyonlarının olmayışı ve denemekten vazgeçmiş halde olmaları durumudur". Bu tanım ile daha önce yapılmış olan öğrenilmiş çaresizlik, örgütsel nevroz ve depresyon tanımları arasındaki benzerlik anlamlıdır.

Örgüt depresyonunun nedenleri ve belirtileri konusunda farklı görüşler vardır. Brunsson'a (1986:164) göre örgütler çoğu zaman, kendi içlerindeki çelişkileri, uyuşmazlıkları, destekle ve yasalara uygunluğa göre değerlendirmektense; sadece yapıları, süreçleri ve sonuçları değerlendirir. Bunun sonucunda da örgütte çatışan bölümler ya da görüşler ortaya çıkar. Akılcı karar verme süreçlerini kullanmada, üretimde, örgüt problemlerinin çözüm aşamasında depresif süreçler gözlenmeye başlanır. Scurlock (1995:10) ise örgüt depresyonu yaşanan örgütlerde, bireylerin bireysel umutlarının boşa çıktığı bir tür felce uğramışlık hissi içinde olduğunu ifade etmektedir. Yazar bu durumun, söz konusu örgütte ciddi yapısal çatlaklar oluşturabileceğine işaret etmekte ve yazara göre bu erezyon özellikle yönetici tabakasında gözlenmektedir. Bilchik (2000:36) ise örgüt depresyonunun bulaşma özelliğine vurgu yapmaktadır. Ona göre örgüt depresyonu örgütteki liderlerden çalışanlara yansıyarak yayılmaktadır. En önemli belirtisi ise "umutsuzluk"tur. Üzerinde durulan bir diğer önemli konu da; depresif bir örgütün çalışanlarını ve kaynaklarını harekete geçirme kapasitesinin düşük olduğu, örgütün aşağıya doğru bir sarmal halinde kendisini kuşatmış bu hastalığa katlandığı 
ve bir müdahale uygulanmadığ 1 sürece kisa zamanda yok olabileceğidir (Cohen ve Cohen, 1993:79).

Örgüt depresyonu belirtileri Frankel (2002:2) tarafından şu şekilde tanımlanmıştir;

*genel olarak gözlenen uyuşukluk hali,

* değişime karşı direnç,

*düşük yaratıcılık ve yeniliklere kapalı olma,

* kabul edilebilir verimliliğin en alt sinırinda yer alma,

* devamsızlıkta artış, geç gelme ve öğle aralarını uzatma gibi davranışlarda artış,

* departmanlar arası ve departman içinde sinurlı iletişim,

* depresif bireylerin çalışma isteksizliği nedeniyle verimde ya da karlilikta azalma

* karar vermede gecikme,

* başarıların ardından sevinç belirtisi göstermeme.

Cohen ve Cohen (1993:80) de benzer biçimde depresyon halindeki bir örgütte çalışan bireylerin, ilgisiz, duygusuz ve uyuşuk olduğunu ifade etmişlerdir. Yazarlara göre depresyondaki örgütler, geleceğe ilgi geçmişe bağlılık göstermez. Aslında depresif bir örgüt depresyonda olduğunu bilir, bundan suçluluk duyar ve bu durumun üstesinden gelmek için çabalamak istemez.

Bilchik (2000:37) ise belirtileri sıralamak yerine, depresyondaki bir örgütün çalışanlarının duygu ve düşüncelerini çalışanların kendi cümleleri ile açıklamaya çalışmaktadir;

"Bu örgütün nereye gittiği hakkında bir fikrim yok",

"Bundan ben sorumlu değilim, ve kimin sorumlu olduğunu da bilmiyorum",

"Herhangi bir şey yapmayacağım, yeni bir görev üstlenmeyeceğim",
"Bu gidişi geriye döndürecek, ama yeni olmayan, bir şeyler istiyorum".

Bilchik (2000:37) ayruca, bir depresyon testindeki maddelerin, örgüt depresyonunda yaşanan duygusal

durumlarla örtüştüğ̈̈nü söyleyerek şu maddelerle durumu örneklemektedir;

"Geleceğimi umutsuz görüyorum",

"Karar vermekte zorluk çekiyorum",

"Hayata ve benim için önemli olan şeylere ilgimi yitirmekteyim",

"Gerginim ve hiçbir şey yapmak istemiyorum",

"Kendimi kapana kısılmış gibi hissediyorum".

Görüldüğü üzere örgüt depresyonu, diğer psikolojik sorunlar gibi, duygusal, bilişsel ve davranışsal düzeyde gözlenmektedir. Klinik depresyondan farkı, örgütün genelinde gözlenmesi ve nedenlerinin örgüt kaynaklı olmasıdır. Söz konusu belirtiler, örgüt depresyonunun yöneticiler tarafından gözlenmesini kolaylaştırmakta ve bu konuda araştırma yapanlara incelenmesi gereken süreçleri işaret etmektedir.

Araştırmalar da örgütlerdeki patolojik yapıya dikkat çekmektedir. Son yıllarda ABD'de, çalışanların depresyon sebebiyle sevk almasındaki artış dikkat çekici boyutlara ulaşmış ve birçok araştırma (Johnson, 1997:359; Burgess, 1999: 37; Park, Wilson ve Lee, 2004:444) konuya dikkat çekmiştir. Söz konusu araştırmalar depresyonun maddi ve manevi açıdan birey ve örgüt için, makro boyutta ülke ekonomisi için zararlarını ortaya koymuştur.

Örgütsel faktörlerin çalışan psikolojisi üzerindeki etkisine ve örgütsel felaketlerin (organizational catastrophe) bütün örgüt üzerindeki olumsuz etkilerine de dikkat çekilmiştir (Barton, 1994:19; Sutherland, 1995:24; Mariott, 2005:3; Baruch ve Lambert, 2007:86). Barton (1994:18) örgütsel felaketlerin çalışanlar üzerindeki etkilerini araştırmıştır. Ona göre örgütsel bir felaketin sonunda yaşanan ruhsal sıkıntılar; hafif dü- 
zeyde depresyondan, manik-depresif bozukluğa ve hatta intihar düşüncelerine kadar değişebilmektedir. Carr (1994:8), devlet okullarındaki müdürler arasında, depresyon ve anksiyetenin yaygınlığına ilişkin araştırma sonuçlarına dikkat çekmiş ve bunun devlet okullarındaki psikolojik yap1nın gelişimi ile ilişkisine işaret etmiştir. Sutherland (1995:17) 1987 ve 1990 yillarında pratisyen hekimlerin sorunlarını araştırmıştır. Araştırmada idari uygulamalar, rutin tıbbi çalışma ve rol stresi, düşük iş doyumu ve düşük psikolojik iyilik halinin en önemli göstergeleri olarak belirlenmiştir. Park, Wilson ve Lee'e (2004:444) göre Amerika'da çalişanların \%9,5'u depresif bozukluk yaşamaktadır. Araştırmacılara göre depresyon, yalnızca kişiyi işinde yetersiz kılmamakta, tıbbi maliyet, devamsızlık ve iş performansındaki düşüşün de etkisiyle örgütsel verimliliği etkilemekte, bu durum da ciddi bir mali yük oluşturmaktadır. Bunların dişında NASA'da yaşanan örgüt depresyonu (Marriott, 2005:12) -1970 y1linda Apollo uzay aracı projesinin sonlandirılması ile başlayan süreç, 1986 yılında Challenger Uzay Mekiği'nin içindeki mürettebatla birlikte patlaması ile su yüzüne çıkmıştır. Kurumun işleyişini inceleyen uzmanlar bu durumu NASA'nın örgüt depresyonu yaşadığ 1 şeklinde yorumlamışlardır- ve örgütsel bir fenomen olan örgütsel anksiyete (Baruch ve Lambert, 2007:84) araştırmalara konu olmuştur.

Bu çalışmanın örneklemini ilköğretim ikinci kademe ve lisede çalışan öğretmenler oluşturmaktadır. Örgüt depresyonunun gözlendiği bir okulda eğitimin temel amaçlarına ve okulun kendi hedeflerine ulaşmasının mümkün olmadığ 1 düşünülmektedir. Son yıllarda okullardaki; şiddet, başarısızlık, yetersiz kalan öğretmen maaşları, öğretmenlerin çalışmaya yönelik isteksizliği gibi birçok sorun gündemde yer bulmuştur. Bireylerin toplumsal hayata hazırlanmaları, gelişimsel özelliklerine uygun olarak yetişmelerine destek olmayı amaçlayan okulların, bu amaca yönelik görevlerini yerine getirmede ne kadar başarılı oldukları tartışma konusu olmaktadır. Örgütü oluşturan üyelerin psikososyal açıdan sağlıklı olması, örgüt etkinliğini ve verimliliğini artıran önemli bir faktördür.

$\mathrm{Bu}$ araştırmanın amacl; bir hareketsizlik, saplanıp kalmış olma ve geleceği planlamada yetersiz kalma hali, örgütteki bireylerin gelecekte ne yapacakları hakkında bir vizyonlarının olmadığ 1 ve denemekten vazgeçtikleri bir çöküntü durumu olarak tanımlanan (Bilchik, 2000:34) örgüt depresyonunu ölçmek için Örgüt Depresyonu Ölçeği'ni geliştirmek ve ölçeğin psikometrik niteliklerini belirlemektir.

\section{YÖNTEM}

Bu araştırma bir ölçek geliştirme çalışmasıdır. Bu bölümde araştırma örneklemi, veri toplama sürecindeki işlem basamakları ve örgüt depresyonu ölçeğinin puanlanmasına ilişkin bilgilere yer verilmiştir.

\subsection{Araştırma Örneklemi}

Araştırma grubunu Ankara'nın Gölbaşı ilçesi ve Ankara merkezdeki sekiz ilköğretim ikinci kademe ve orta öğretim okulunda çalışan 282 kişilik bir öğretmen gurubu oluşturmuştur.

\section{2. İşlem}

1-Ölçek maddeleri, araştırmacı tarafından ilgili literatür gözden geçirilerek ve uzman görüşlerine başvurularak hazırlanmıştır. Bu süreçte, Bilchik'in (2000:38) 15 maddelik "Örgütünüz İçin Depresyon Kontrol Listesi" soruları da dikkate alınmıştır. Cohen ve Cohen'in (1993:175) örgütleri farklı psikolojik boyutlarda inceleyen -mani, manik depresif, depresyon, paronoya, şizofren, nevrotik davranış, obsesif kompulsif bozukluk gibi"Organizational Health Analyzer (OHA)" isimli ölçme aracı da incelenmiş fakat ölçek maddeleri klinik depresyona daha uygun bulunduğu için sözü edilen ölçekten yararlanılamamıştır. Maddelerin oluşturulması sürecinde Örgüt Depresyonu konusundaki literatürü inceleyen psikolojik danışma ve rehberlik alanındaki bir profesör ve iki bilim uzmanının görüşüne başvurulmuştur. İlgili kuramsal görüşler ve ölçme araçları çerçe- 
vesinde bir örgütün depresyonda olup olmadığını ölçmek için geliştirilecek bir ölçme aracındaki maddelerin; kurumun gelişime dönüklüğü, kurum içi demokrasi ve çalışma motivasyonu konularını içermesi gerektiği sonucuna varılmıștır. Oluşturulan maddelerin dengeli biçimde olumlu ve olumsuz ifadelerden oluşmasına ve karamsarlık, umutsuzluk, ilgisizlik, isteksizlik gibi depresif duygular içermesine özen gösterilmiştir.

Bu doğrultuda Örgüt Depresyonu Ölçeği'ni geliştirmek için ilk olarak, 55 maddelik madde havuzu oluşturulmuştur. 55 maddelik madde havuzu, psikolojik danışma ve rehberlik alanında bilim uzmanı altı kişi ve bir profesörün görüşüne sunulmuştur. Uzman görüşleri sonunda bu sayı 45 maddeye indirilmiştir. 45 maddelik taslak form sekiz farklı okulda çalışan 300 öğretmene uygulanmıştır. Bu formlardan 290 form geri dönmüştür, fakat bu formların sekizi eksik doldurulduğu için değerlendirmeye alınmamıştır. Böylece 282 form üzerinden değerlendirme yapılmıştır.

2-Ölçeğin yapı geçerliğini ortaya koymak ve ölçekte yer alan maddelerin faktör yüklerinin belirlenerek boyutlandirılması amacıyla faktör analizi yapılmıştır. Ölçekte yer alan maddelerin benzer davranışları ölçtügünü belirlemek için, her maddeden alınan puanlar ile ölçeğin toplam puanı arasındaki ilişki (madde-toplam puan korelasyonu) hesaplanmıştır.

3-Ölçeğin geçerliğini test etmek için 282 kişilik örneklemden tesadüfi olarak seçilen 35 kişilik bir öğretmen grubuna "Maslach Tükenmişlik Envanteri" de uygulanmış ve bu yolla benzer ölçekler geçerliğine bakılmiştır.

4-Ölçeğin güvenirlik çalışması için Cronbach Alpha Katsayısı formülü kullanılmıştır. Ayrica test tekrar test yöntemiyle ölçek üç hafta arayla aynı gruba tekrar uygulanmiştır.

5-Faktör yükleri ve madde-toplam korelasyonları katsayısı düşük olan maddeler ölçekten çıkartıldıktan sonra 42 maddelik nihai ölçek ortaya çıkmıştır.

\section{3.Örgüt Depresyonu Ölçeği'nin Puanlan- mast}

Örgüt Depresyonu Ölçeği 42 maddeden oluşmaktadır. Ölçek maddeleri likert tipindedir ve 1-5 arasında puanlanmaktadır. Ölçekte en olumlu cevap en yüksek puanı almaktadır. Böylece ölçekten alınan en yüksek puan 210 olurken, alınacak en düşük puan 42 olmaktadır. Olumsuz ifadeler tersine puanlanmaktadır (5'ten 1'e doğru). 42 ve $210^{\prime}$ nun orta noktası $126^{\prime}$ dir. Alt ve üst \%27'lik dilim 70-182 arasında kalan puan dilimidir. Alınan puanın yüksek olması örgüt depresyonunun düşük olduğunu göstermektedir.

\section{BULGULAR}

Ölçeğin yap1 geçerliğini tespit etmek amacıyla 45 maddelik ilk form 300 kişilik bir öğretmen grubuna uygulanmış ve değerlendirme hatasız 282 form üzerinden yapılmıştır. Öncelikle örneklem büyüklüğünün yeterliliğini test etmek amacıyla KaiserMeyer-Olkin (KMO) değeri ve örneklem dağlımının normallik varsayımını karşılayıp karşılamadığını test etmek için Barlett Küresellik Testi sonuçları incelenmiştir. KMO değeri, seçilen örneklem verilerinin faktör çıkarmak için uygun olup olmadığına karar vermenin bir ölçüsü olarak kullanılmaktadır. KMO değerinin .50'den yüksek olması, faktör analizine devam edilebileceği anlamına gelir. Ancak oran ne kadar yüksek olursa, veri seti faktör analizi yapmak için o kadar iyidir. Bu analizde KMO değerinin .90 olduğu saptanmıştır. Bu da "çok iyi" olarak nitelendirilebilir (Kalayc1, 2005:322). Yine Barlett Küresellik Testi değerinin de anlamlı olduğu [ =7758.556, p < 0.01] belirlenmiştir. $\mathrm{Bu}$ sonuç örneklem dağılımının normallik varsayımını karşıladığını göstermektedir. Bu bulgular doğrultusunda, veri setinin faktör analizi yapmak için uygun olduğuna karar verilmiştir (Kalayc1, 2005:322; Şencan, 2005:384).

Faktör Analizi sonucunda "Örgüt Depresyonu Ölçeği" maddeleri .30'un altında 
değer veren, 21, 24 ve 25'inci maddeler (Tablo 1) hariç tek faktör altında toplanmıştır. Söz konusu maddeler ölçekten çıkartılmiştır. Ölçekteki maddelerin faktör yük değerleri.301 ile.816 arasında değişmektedir. Kalan maddelerin madde-toplam korelasyonları incelendiğinde ise, 0.313 ile 0.777 arasında değiștiği görülmektedir (Tablo 2). Bu faktörün tek başına açıkladığ 1 varyans \%38.384 ve Cronbach-Alpha güvenirlik katsayısı ise 0.941 'dir.

\section{Tablo 1}

\section{Ölçekten Çıkarılan Maddeler}

\begin{tabular}{|l|l|}
\hline 21 & Kurumumda dedikodu çok yapılır \\
\hline 24 & Kurumum merkeziyetçi yapıdan uzaktır \\
\hline 25 & Birimler arasındaki iletişim sınırlıdır \\
\hline
\end{tabular}

\section{1. Ölçeğin Benzer Ölçek Geçerliği ve Test Tekrar Test Güvenirliği}

Tükenmişlik, 1970'li yılların başlarında Freudenberger, Maslach ve Pines tarafından ayrı ayrı tanımlanmış ve son 20-30 yıldır üzerinde yoğun çalışılan bir kavram olmuştur. Birçok araştırmacı tükenmişliğin, beklentiler, tutumlar, güdüler ve duygular içeren, bireysel düzeyde ortaya çıkan, içsel, psikolojik bir deneyim olduğu konusunda karar birliğine varmışlardır. Tükenmişliğe yol açtı̆̆ 1 düşünülen bireysel faktörler kadar örgütsel faktörlerden de söz edilmektedir. Tükenmişliğe yol açtığ 1 düşünülen örgüte ilişkin faktörler; örgütteki rol karmaşası, rol belirsizliği, karar verme sürecine katılmama, idarecinin/yöneticinin desteğinin ve örgütte ödüllendirme sisteminin olmaması, çalışılan örgütün bulunduğu çevrenin sosyoekonomik düzeyi, ayrıca çalışılan ortam, işten soğuma, yetersiz eğitim, uzun süre yaşanan iş

Tablo 2

Örgüt Depresyonu Ölçeği Faktör Analizi Sonucu

\begin{tabular}{|c|l|c|c|}
\hline $\begin{array}{c}\text { Madde } \\
\text { No }\end{array}$ & \multicolumn{1}{|c|}{ Maddeler } & $\begin{array}{c}\text { Faktör- } \\
\text { Yük } \\
\text { Değeri }\end{array}$ & $\begin{array}{c}\text { Madde- } \\
\text { Toplam } \\
\text { Korelasyonu }\end{array}$ \\
\hline 1 & Kurumumda çatışmalara yapı̈ı çözümler getirilir. &, 684 &, 642 \\
\hline 2 & Çalışanların düşüncelerine saygı gösterilir &, 691 &, 644 \\
\hline 3 & Kişilerarası iletişim yapıcı olmaktan çok yıkıcıdır. &, 467 &, 459 \\
\hline 4 & Çalışanlarda genel olarak bir halsizlik hali mevcuttur. &, 637 &, 605 \\
\hline 5 & Çalışanların görev, yetki ve sorumluluklarında belirsizlik vardır. &, 492 &, 481 \\
\hline 6 & Kurumum yeniliklere açıtır. &, 301 &, 290 \\
\hline 7 & Çalışanlar teşvik edilip ödüllendirilir. &, 729 &, 698 \\
\hline 8 & $\begin{array}{l}\text { Karar almadan önce her düzeydeki çalışanların fikirleri alınır ve değerlendi- } \\
\text { rilir. }\end{array}$ &, 689 &, 658 \\
\hline 9 & Bu kurumda çalıştı̆̆ım için kendimi değerli ve şanslı hissediyorum. &, 700 &, 658 \\
\hline 10 & Çalışanlar kurumun geleceği konusunda umutsuzdur. &, 583 &, 560 \\
\hline 11 & Çalışanlar şevkle çalışmaktadır. &, 636 &, 578 \\
\hline 12 & Her zaman yönetimin görüşü uygulanır. &, 496 &, 493 \\
\hline 13 & Farklı görüşlere karşı çıkılır. &, 416 &, 391 \\
\hline 14 & Kurumum sürekli gelişmekte ve ilerlemektedir. &, 723 &, 678 \\
\hline 15 & Çalışanların sorunlarıyla hemen ilgilenilir ve giderilmeye çalışılır. &, 810 &, 777 \\
\hline 16 & Çalışanların çoğu işini severek yapmaz. &, 545 &, 530 \\
\hline 17 & $\begin{array}{l}\text { Çalışanlar gereksiz işlerle uğraşmaktan, gerçek işlerini tam olarak yapama- } \\
\text { maktadır. }\end{array}$ &, 505 &, 491 \\
\hline 18 & Çalışanların çoğu iş yerinde mutsuzdur. &, 635 &, 616 \\
\hline 19 & Çalışanlar birbirlerinin gelişmelerine yardımcı olmaktadır. &, 636 &, 587 \\
\hline 20 & Çalışma ortamımız her zaman iyileştirilir. &, 816 &, 759 \\
\hline
\end{tabular}




\section{Tablo 2}

Örgüt Depresyonu Ölçeği Faktör Analizi Sonucu

\begin{tabular}{|c|l|c|c|}
\hline $\begin{array}{c}\text { Madde } \\
\text { No }\end{array}$ & \multicolumn{1}{|c|}{ Maddeler } & $\begin{array}{c}\text { Faktör- } \\
\text { Yük } \\
\text { Değeri }\end{array}$ & $\begin{array}{c}\text { Madde- } \\
\text { Toplam } \\
\text { Korelasyonu }\end{array}$ \\
\hline 22 & Kurumumdaki değişimler ümit vericidir. &, 771 &, 734 \\
\hline 23 & Kurumun fiziki koşulları bakımsızdır. &, 396 &, 362 \\
\hline 26 & Kurumum yeni şeyler öğrenmeye elverişlidir. &, 722 &, 682 \\
\hline 27 & Bürokratik nedenlerden kurumum gelişememektedir. &, 505 &, 484 \\
\hline 28 & Kurumumda gelişim için planlar yapılır ve uygulanır. &, 752 &, 707 \\
\hline 29 & Kurumumda çalışanların ihtiyaçları giderilmeye çalışılır. &, 787 &, 738 \\
\hline 30 & İdare ile uyum ve işbirliği içinde çalışılmaktadır. &, 759 &, 711 \\
\hline 31 & Yönetim çalışanlara eşit davranmaz. &, 621 &, 593 \\
\hline 32 & Çalışanlar öğrencilerin sorunlarını dinlemeye açıktır. &, 488 &, 466 \\
\hline 33 & Çalışanların çoğu ek sorumluk almak istemez. &, 518 &, 503 \\
\hline 34 & $\begin{array}{l}\text { Yönetim, çalışanların yetenek ve becerilerini geliştirmesi için bütün imkanla- } \\
\text { rını kullanır. }\end{array}$ &, 758 &, 716 \\
\hline 35 & Kurumumda işler yavaş ilerler. &, 607 &, 597 \\
\hline 36 & Çalışma koşullarımdan memnunum. &, 619 &, 584 \\
\hline 37 & Kurumumda politika ve prosedürlere daima uyulur. &, 408 &, 375 \\
\hline 38 & Değerlendirmeler nasıl çalıştı̆̆ıma göre yapılır. &, 712 &, 668 \\
\hline 39 & Çalışanlarda işe geç kalma çok olur. &, 425 &, 422 \\
\hline 40 & Çalışanların fikirleri, projeleri idare tarafından dinlenir ve desteklenir. &, 709 &, 680 \\
\hline 41 & Çalışanlar değişime direnç gösterir. &, 309 &, 313 \\
\hline 42 & Çalışanların performansı düşüktür. &, 454 &, 451 \\
\hline 43 & Çalışmamın kalitesi hakkında, düzenli olarak geri bildirim alırım. &, 549 &, 516 \\
\hline 44 & Bir çatışma durumunda herkes birbirini suçlar. &, 799 &, 487 \\
\hline 45 & Kurumumda yenilikler takip edilir. &, 772 \\
\hline
\end{tabular}

KMO=0.906.516

Barlett Küresellik Testi: $\chi^{2}=7758.556, P<0.01$

Açıklanan Varyans= $\% 38.384$

Cronbach-Alpha=0.94

Madde Sayısı: 42

stresi ve stresle baş etmedeki başarısızlığın fark edilmesi (Gold,1985; Sarros ve Sarros, 1987; Wisniewski ve Gargulo, 1997 Akt; Akçamete, Kaner ve Sucuoğlu, 2001) tükenmişliğe neden olabilmektedir. İşin niteliği ve iş ortamina ilişkin nedenlerin çokluğu, tükenmişlik kavramı ile örgüt depresyonunu yakın iki kavram yapmaktadır. Geçerlik çalışmasında bir tükenmişlik ölçeğinin tercih edilmesi de bu sebepledir.

Benzer ölçekler geçerliği için kullanılan Maslach Tükenmişlik Envanteri, Maslach ve Jackson (1981; Akt: Ergin, 1992:43) tarafından geliştirilmiş ve Ergin (1992:43) tarafından Türkçe'ye uyarlanmıştır.
Tükenmişliği üç alt evrede değerlendiren Maslach Tükenmişlik Envanteri'nin ilk alt ölçeği 9 maddeden oluşan duygusal tükenme, ikincisi 5 maddeden oluşan duyarsızlaşma, üçüncüsü 8 maddeden oluşan kişisel başarısızlık alt ölçeğidir. 22 maddenin toplamı da toplam tükenmişlik puanını vermektedir. Ölçeğin son yapılan güvenirlik çalışmasında duygusal tükenme, duyarsızlaşma, kişisel başarısızlık alt boyutları için Cronbach Alfa güvenirlik katsayıları sırasıyla; .75, .62, .71 bulunmuştur. Testin toplamina ilişkin Cronbach Alfa güvenirlik katsayısı ise .80 bulunmuştur (Babaoğlan, 2006:56). 
Örgüt depresyonu Ölçeği, Maslach Tükenmişlik Envanteri ile birlikte 35 kişilik bir öğretmen grubuna uygulanmıştır. İki ölçeğin toplam puanları arasındaki korelasyon $\mathrm{r}=.77$, tükenmişlik envanterinin alt ölçekleri ile örgüt depresyonu ölçeğinin toplam puanı arasındaki korelasyonlar; duygusal tükenmişlik: $\mathrm{r}=.79$, kişisel başarı: $\mathrm{r}=.57$, $\mathrm{du}$ yarsızlaşma: $r=.54$ bulunmuştur. Örgüt Depresyonu Ölçeği 35 kişilik öğretmen grubuna 3 hafta arayla tekrar uygulanmıştır ve test tekrar test güvenirlik puanları; [ $\mathrm{r}=.91$; $\mathrm{p}<.01$ ] bulunmuştur.

\section{SONUÇ VE ÖNERILER}

Örgütleri oluşturan da bireylerdir. Bu nedenle örgütler de bireyler gibi psikolojik tepkiler vermektedir. Modern toplumu oluşturan yapılar olan örgütlerin sağlığı, toplumun sağlığ 1 ile çok yakından ilgilidir. Bireysel olarak yaşanan patolojik durumlar büyük ölçüde bireyi ve yakın çevresini olumsuz etkilerken, bir örgütteki patolojik bir durum, örgütün büyüklüğü ve toplumdaki önemi ölçüsünde bütün bir toplumu etkileyecek kadar büyük sonuçlara yol açabilir. Bu çalışmada temel alınan ve bir toplumun yarınlarının mirasçısı bireylerin yetişmesinden sorumlu okulların örgütsel yapısı, çalışanlar ve öğrenciler için sağlıklı bir atmosfer oluşturamadığ 1 takdirde, söz konusu örgütler asıl amacindan uzaklaşmış olacaktır. Bu durum toplumun geleceği için bir tehdit olarak düşünülebilir.

Son yılarda çalışanların, iş doyumu, tükenmişliği, depresyonu, iyilik hali konularında ölçme araçları geliştirilmekte, bu sorun ve olguların öncül ve sonuçlarına ve birbiriyle ilişkisine yönelik önemli veriler toplanmaktadır. Ancak örgütün geneline ya da bir departmanın tümüne yayılmış, yılgınlık, isteksizlik gibi belirtilerle ortaya çıkan, depresif atmosfere ilişkin araştırmalar sınırlıdır. Her örgüt kendi geleceği için psikolojik yapısını düzenli olarak gözden geçirebilir, buna hizmet edecek araştırmalar yapabilir.

Bir örgütün mevcut duygusal durumunun tespit edilmesi, olumlu ve olumsuz süreçlerin farkına varılmasını sağlayacağı gibi, sorunla baş etme stratejilerinin geliştirilmesine de hizmet edecektir. Asıl önemli konu, örgüt depresyonunun tespit edildiği kurumlarda, bu durumla mücadele için geliştirilecek yaklaşımlardır. Bu yaklaşımlar farklı bakış açılarına göre geliştirilebilir. Bundan sonraki çalışmalar bu yaklaşımların geliştirilmesini konu edinebilir.

$\mathrm{Bu}$ araştırmada okuldaki örgüt depresyonunu ölçemeye ilişkin bir araç geliştirilmiştir. Bu çalışma yeni çalışmalar için örnek oluşturabilir ve böylece farklı örgütlerin psikolojik yapılarını ölçmeye ilişkin araçlar geliştirilebilir. 


\section{Kaynaklar}

Akçamete, G., Kaner, S. ve Sucuoğlu, B. (2001). Öğretmenlerde Tükenmişlik İş Doyumu. Ankara: Nobel Yayın Dağıtım

Aytaç, Ö. (2004). Örgütler Sosyolojik Bir Perspektif. Fırat Üniversitesi Sosyal Bilimler Dergisi, 14 (1), 189-217. Elazığ.

Babaoğlan , E. (2006). İlköğretim Okulu Yöneticilerinde Tükenmişlik. Yayınlanmamış Doktora Tezi, Abant İzzet Baysal Üniversitesi, Sosyal Bilimler Enstitüsü, Bolu.

Barton , L. (1994). Trauma in the Aftermath of Organizational Ctastrophe: The Short -and Long- term Impact on Employees and their Supervisors. Disaster Prevention and Menagement, 3 (3) , 18-26.

Baruch, Y. \& Lambert ve R. (2007). Organizational Anxiety: Applying Psychological Concepts into Organizational Theory. Journal of Managerial Psychology, 22 (3), 84-99.

Beck, A.T. \& Alford, B.A. (2009). Depression: Causes and Treatment. Second edition. University of Pensylvania Press.

Bilchik, G. S. (2000). Organizational Depression. H\&HN. Hospitals \& Health Networks, 74 (2), 34-38

Burgess, A.G. (1999). Managing Workplace Depression. Behavioral Health Management, 19 (3) , 37

Brunsson, N. (1986). Organizing for inconsistencies: On organizational conflict, depression and hypocrisy as substitutes for action. Scandinavian Journal of Management Studies, 2 (3-4), 165-168.

Carr, A. (1994). The Psychosructure of Work: "Bend Me, Shape Me, Anyway You Want Me, as long as You Love Me It's Alright". Journal Workplace Learning, 6 (3) , 7-10.

Cohen, W. \& Cohen , N. (1993) The Paranoid Corporotion: And 8 other ways your company can be crazy. Advice from on organizational shrink. Newyork American Management Assocation. Emerald.
Ergin, C. (1992). Doktor ve Hemşirelerde Tükenmişlik ve Malasch Tükenmişlik Ölçeğinin Uyarlanması. VII. Ulusal Psikoloji Kongresi Bilimsel Çalışmalar,. 22-25 Eylül 1992.

Frankel, L. (2002). What to Do If Your Company is "Depressed", from http:/ / www.fabjob.com/tips194.html

Frankel, L. (1992). Depressed Organizations : İdentifying the Symptoms and Overco. Employment Relations Today Haboken: Winter 1991/1992, 18 (4), 443-452.

Güler, B.,K. (2006). Çalışma Hayaıda Öğrenilmiş Çareszilik. 1. Baskı. Liberte Yayınları. Ankara

Johnson, P. (1997). The Boomer Blues: Depression in the Workplace. Public Personel Management, 26 (3), 359-366

Kalaycı, Ş. (2005). SPSS Uygulamalı Çok Değişkenli İstatistik Teknikleri. Ankara, Asil Yayın Dağıtım.

Mariott, D. (2005). NASA Chief's Vision is on Track. USA Today, ISSN: 0734-7456.

Overby, S. (2002). Leadership Corporate. CIO, April, http://www.cio.com/article/30979/

Park, K.O., Wilson, M.G. \& Lee, M.S. (2004). Effects of Social Support at Work on Depression and Organizational Productivity. American Journal of Health Behavior, 28 (5), 444-455.

Scurlock, J. (1995). What's big and blue? Psychology Today, 28 (3), 10-11

Schwarz, O.J. (2007). Assessing Future Disorders in Organizations: Implications for Diagnosing and Treating Schizopherenic, Depressed or Paranoid Organizations. Foresight, 9 (2), 15-26.

Sutherland, V.J. (1995). Stress and The New Contract for General Pratitioners. Journal of Managerial Psychology, 10 (3), 17 28.

Şencan, H. (2005). Sosyal ve Davranışsal Ölçümlerde Güvenilirlik ve Geçerlilik. Ankara, Seçkin Yayıncılık. 